\title{
Inventory of benthic amphipods from fine sand community of the Iberian Peninsula east coast (Spain), western Mediterranean, with new records
}

\author{
José ANTONio DE-LA-OSSA-CARRETERo ${ }^{1}$, JEAN-CLAUdE DAUVIN ${ }^{2,3}$, YOANA DEL-PILAR-RUSO ${ }^{1}$, \\ FRANCISCA GIMÉNEZ-CASALDUERO ${ }^{1}$ AND JOSÉ LUIS SÁNCHEZ-LIZASO ${ }^{1}$ \\ ${ }^{1}$ Department of Marine Sciences and Applied Biology, University of Alicante, Apartado 99 E-0308o Alicante, Spain, ${ }^{2}$ Universite de \\ Lille Nord de France, 59000 Lille, France, ${ }^{3}$ Université de Lille 1, Station Marine de Wimereux, UMR LOG, 28 Avenue Foch, BP 80, \\ F-62930 Wimereux, France
}

\begin{abstract}
Recent sampling surveys (2004-2008) of the shallow (12-20 m) soft-bottom homogeneous fine-sand community have allowed the collection of 55 marine amphipod species (53 Gammaridea and 2 Caprellidea) along the $250 \mathrm{~km}$ of Iberian Peninsula east coast (Spain, Mediterranean Sea). Among the species recorded, one recently described is new to science, five were collected for the first time in the Spanish Mediterranean and 14 were recorded for a second time confirming their presence. Of these 20 species; six are considered to be endemic to the Mediterranean Sea, seven are also north-eastern Atlantic species, and the last seven have a wide geographical distribution in the Indo-Pacific or Arctic and the Atlantic Oceans. Finally, multivariate analyses of species distribution showed changes among locations according to the northsouth axis and depth, parameters that highly influence the benthic communities.
\end{abstract}

Keywords: amphipods, Mediterranean, Spain, fine-sand

Submitted 29 June 2010; accepted 1 October 2010

\section{INTRODUCTION}

The Mediterranean Amphipoda fauna has a high richness, with more than 452 recorded species (Bellan-Santini et al., 1998), and has been widely studied; however, the knowledge of this order is not uniform throughout the entire Mediterranean. In this way, knowledge of the ecology and taxonomy of amphipod species on the Mediterranean coast of the Iberian Peninsula is still fragmentary (Jimeno \& Turón, 1995; Bellan-Santini et al., 1998) and the central east coast has been studied relatively infrequently (Marti, 1989).

According to Jimeno (1993), there are 368 known species along the coast of the Iberian Peninsula, of which only 146 are reported from the Mediterranean side. Works on amphipods from this area have been mainly carried out on the Catalan coast (Castany et al., 1982; Bibiloni, 1983; Carbonell, 1984; Jimeno, 1993; San Vicente \& Sorbe, 1999; Munilla \& San Vicente, 2005; Cartes et al., 2007, 2009; Delgado et al., 2009) and the Andalucia coast (Conradi et al., et al., 2007; Gonzalez et al., 2008; Guerra-García et al., 2009a, b; Izquierdo \& Guerra-García, 2010; Guerra-García \& Izquierdo, 2010). Other studies have been produced in the 1995; Conradi \& López-González, 1999; Sánchez-Moyano

Balearic Islands (Cartes et al., 2003; Ortiz \& Jimeno, 2003) and indeed, on the Iberian Peninsula east coast (Marti, 1989; Sánchez-Jerez et al., 1999; Vázquez-Luis et al., 2008, 2009), where this study was carried out (Figure 1); however, more studies on the distribution of amphipods are still required in order to increase the knowledge of species distribution and amphipod diversity of this area.

One of the communities more frequent in shallow softbottom non-vegetated areas from the western Mediterranean is the medium-to-fine sand community of Spisula subtruncata (Cardell et al., 1999). This community tends to colonize exposed or semi-exposed sublittoral habitats, from the beach environment to $30 \mathrm{~m}$ depth (Sardá et al., 1996, 2000; Cardell et al., 1999). Although this community generally contains low numbers of individuals and low values of biomass, a high abundance and diversity of amphipods had been reported (Bakalem et al., 2009).

The main objective of this paper was to report the status of the knowledge of the amphipod species inhabiting this widely distributed community on the eastern Spanish Mediterranean coast and to analyse changes in species composition among sampled locations.

\section{MATERIALS AND METHDDS}

Corresponding author:

J.A. De-La-Ossa-Carretero

Email: ja.ossa@ua.es
A total of 40 stations from ten different locations along approximatley $250 \mathrm{~km}$ of south-west coast of the Balearic 


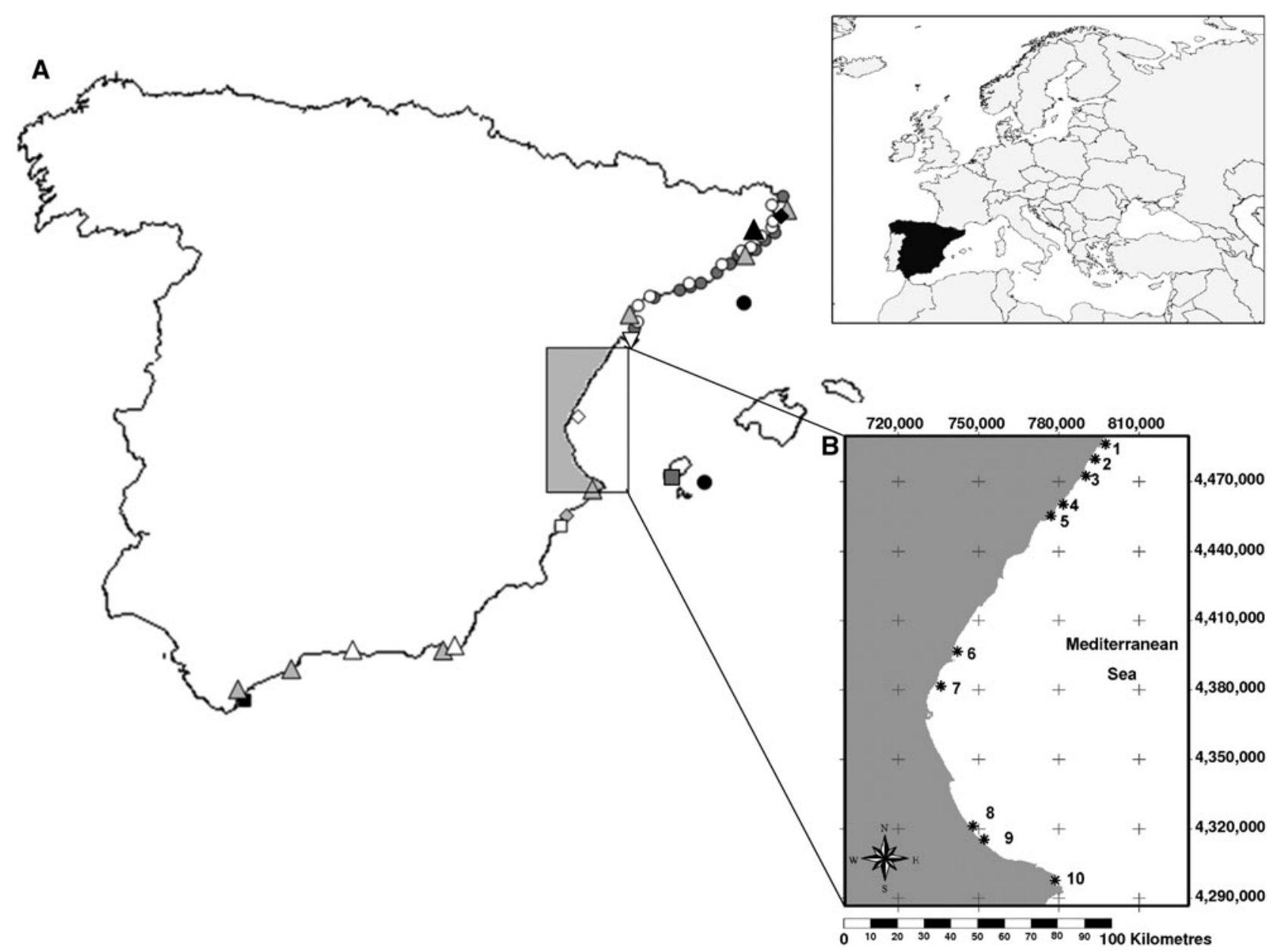

Fig. 1. (A) Locations from the literature about amphipods checked from the Spanish Mediterranean coast: $\bullet$, Carbonell (1984); $\mathbf{\Lambda}$, Bibiloni (1983); $\diamond$, Marti (1989); @, Jimeno (1993), Jimeno \& Turón (1995); \$, Sánchez-Jerez et al. (1999, 200o); D, Conradi et al. (1995), Conradi \& López-González (1999), Sánchez-Moyano et al. (2007), Guerra-García et al. (2009a); O, San Vicente \& Sorbe (1999); Munilla \& San Vicente (2005); A, Guerra-García et al. (2009b), Guerra-García \& Izquierdo (2010), Izquierdo \& Guerra-García (2010); •, Cartes \& Sorbe (1993, 1999), Cartes et al. (2003); $\nabla$, Cartes et al. (2007, 2009), Delgado et al., 2009; 口, Ortiz \& Jimeno, 2003; $\square$, Vázquez-Luis et al. (2008, 2009); $\triangle$, Gonzalez et al. (2008); (B) locations from this study: 1, Vinaroz; 2, Benicarló; 3, Peñíscola; 4, Alcossebre; 5, Torreblanca; 6, Canet d'en Berenguer; 7, Puebla de Farnals; 8, Gandia; 9, Oliva; 10, Javea.

Basin (Comunidad Valenciana, Iberian Peninsula east coast) were sampled (Figure 1). All locations were characterized by homogeneous fine-sand sediment (median sediment included between $0.125 \mu \mathrm{m}$ and $0.25 \mu \mathrm{m}$ ) with a depth-range from 12.4 to $20 \mathrm{~m}$ (Table 1 ). For each location, four sites were sampled, keeping a constant depth in each location. All samples were collected in July during five consecutive years (2004 to 2008). Four Van Veen grab samples $\left(400 \mathrm{~cm}^{2}\right)$ were obtained at each site. Three samples were sieved through a $0.5-\mathrm{mm}$ screen, fixed in $10 \%$ formalin and preserved in $70 \%$ ethanol for the study of the amphipod assemblage. The other sample was used to characterize the sediment (granulometric analysis and organic content). Grain size analysis was assessed by standard sieve fractionation (Holme \& McIntyre, 1984). Organic content of dry sediment was estimated as the loss of weight after ashing.

Table 1. Locations, geographical coordinates, depth $(\mathrm{m})$ and physical characteristics of sediment of the stations of each location.

\begin{tabular}{|c|c|c|c|c|c|c|c|c|c|}
\hline Location & Latitude & Longitude & Depth & $\%$ Mud & $\%$ Fine sand & $\%$ Medium sand & $\%$ Coarse sand & \% Gravel & $\%$ Organic matter \\
\hline 1. Vinaroz & $40^{\circ} 28.15^{\prime} \mathrm{N}$ & $0^{\circ} 30.44^{\prime} \mathrm{E}$ & 15.0 & 4.25 & 78.85 & 5.14 & 9.27 & 2.50 & 2.47 \\
\hline 2. Benicarlo & $40^{\circ} 24.55^{\prime} \mathrm{N}$ & $0^{\circ} 27.70^{\prime} \mathrm{E}$ & 14.0 & 7.56 & 73.55 & 5.68 & 6.79 & 6.43 & 1.61 \\
\hline 3. Peñiscola & $40^{\circ} 20.79^{\prime} \mathrm{N}$ & $\mathrm{O}^{\circ} 24.99^{\prime} \mathrm{E}$ & 14.8 & 1.49 & 83.56 & 4.27 & 5.62 & 5.07 & 2.02 \\
\hline 4. Alcossebre & $40^{\circ} 14.45^{\prime} \mathrm{N}$ & $\mathrm{O}^{\circ} 18.55^{\prime} \mathrm{E}$ & 12.4 & 1.03 & 74.34 & 14.01 & 5.64 & 4.98 & 1.56 \\
\hline 5. Torreblanca & $40^{\circ} 11.83^{\prime} \mathrm{N}$ & $0^{\circ} 14.59^{\prime} \mathrm{E}$ & 13.9 & 1.23 & 86.82 & 5.63 & 3.96 & 2.36 & 1.47 \\
\hline 6. Canet d'en Berenguer & $39^{\circ} 40.96^{\prime} \mathrm{N}$ & $0^{\circ} 10.77^{\prime} \mathrm{W}$ & 15.6 & 0.72 & 83.36 & 5.87 & 9.16 & 0.88 & 1.62 \\
\hline 7. Puebla de Farnals & $39^{\circ} 31.97^{\prime} \mathrm{N}$ & $0^{\circ} 15.44^{\prime} \mathrm{W}$ & 18.9 & 9.18 & 69.05 & 8.36 & 9.32 & 4.09 & 2.61 \\
\hline 8. Gandia & $39^{\circ} 0.15^{\prime} \mathrm{N}$ & $0^{\circ} 8.31^{\prime} \mathrm{W}$ & 16.5 & 1.76 & 88.91 & 4.50 & $3 \cdot 32$ & 1.50 & 2.02 \\
\hline 9. Oliva & $38^{\circ} 56.92^{\prime} \mathrm{N}$ & $0^{\circ} 5.55^{\prime} \mathrm{W}$ & 15.6 & 1.79 & 91.94 & 3.33 & 1.54 & 1.39 & 2.46 \\
\hline 10. Javea & $38^{\circ} 46.83^{\prime} \mathrm{N}$ & $0^{\circ} 12.60^{\prime} \mathrm{E}$ & 20.0 & 7.77 & 75.71 & 12.55 & 3.09 & 0.88 & 1.61 \\
\hline
\end{tabular}


Amphipods were identified using the key of Mediterranean amphipod fauna established by Bellan-Santini et al. (1982, 1989, 1993, 1998), except for the genus Bathyporeia, which was identified using d'Udekem d'Acoz \& Vader (2005). The taxonomy was validated using the ERMS referential for amphipod introduced by Bellan-Santini \& Costello (2001) (http://www.marbef.org/data/erms.php, consulted on 25 May 2010). New records for the Mediterranean Spanish coast were checked using published available literature (Figure 1).

Non-parametric multivariate techniques were used to compare species composition among locations. All multivariate analyses were performed using the PRIMER v. 6 statistical package (Clarke \& Warwick, 1994). Triangular similarity matrices were calculated through the Bray-Curtis similarity coefficient using abundance values that were previously square root transformed. Locations were classified into groups according to the cluster analysis of Bray-Curtis similarity coefficients. Similarities percentage analyses (SIMPER) of abundances were used to determine the species with higher percentage contribution in dissimilarity between groups.

The BEST procedure was used to determine the parameter (granulometry, organic matter \%, depth and latitude) most correlated with species composition changes between sampled stations. Spearman correlation between similarity matrices of samples based on the abundances of benthic community and parameters was determined. Canonical correspondence analysis (CCA) was used to identify the relationships among the spatial distribution patterns of amphipods and environmental gradients. The CCA was conducted using the software CANOCO. The output is displayed as biplot, in which the plotted points for stations can be related to environmental gradients that are represented as arrows. The strength of the correlation of an environmental variable is reflected in the length of the arrow, and its association is reflected in the acuteness of the angle with the axis. Thus, the relationships among stations and environmental variables can be displayed on one plot.

\section{RESULTS AND DISCUSSIDN}

\section{Taxonomic composition}

A total of 55 species, belonging to 38 genera and 22 families, were identified. Among them, five species were first reported from the Mediterranean Spanish coast, 14 species were recorded for the second time and this study confirms their presence along the Spanish Mediterranean coast. A new species of Medicorophium, M. longisetosum sp. nov. (Myers et al., 2010) was also described from this collection.

The species list is reported in Table 2, indicating when each species was previously cited and the bottom type where it was found. Some details on the new and second species records are given.

Order AMPHIPODA Latreille, 1816

Suborder GAMMARIDEA Latreille, 1803

Family AMPELISCIDAE Costa, 1957

Ampelisca sarsi Chevreux, 1888

This species is common on fine-sand shallow water (10$108 \mathrm{~m}$ depth) of the eastern Atlantic Ocean from the western part of the Channel, where it can form abundant populations, to the African coast of Senegal, and in the Mediterranean Sea where it was present in the Marseilles Gulf and in the Adriatic Sea (Bellan-Santini et al., 1982; Bellan-Santini \& Dauvin, 1988). It was also present along the Algerian coast in the Bou Ismail and Algiers Bays and the Bejaia Gulf from 13 to $120 \mathrm{~m}$ on diverse types of sediment from mud to coarse sand (Bakalem \& Dauvin, 1995). Ampelisca sarsi was also recorded at $383 \mathrm{~m}$ from the Portugal coast (Marques \& Bellan Santini, 1993). From the Spanish Mediterranean coast, A. sarsi was previously reported as a first record by Conradi \& López-Gonzalez (1999) among Bugula neritina and Mesophillum in Algeciras Bay (Andalucían coast). This species has been recorded from Vinaroz to Puebla de Farnals and always in low abundances. A total of 64 individuals have been collected from 12.4 to $15.6 \mathrm{~m}$.

\section{Ampelisca spinifer Reid, 1951}

It was observed in the eastern Atlantic Ocean from Ireland to the Liberia coast, and in the Mediterranean in the Marseilles Gulf, the Tyrrhenian Sea and the coast of Israel (Bellan-Santini et al., 1982; Bellan-Santini \& Dauvin, 1988). It was also recorded in Bou Ismail Bay in mud and muddygravel between 25 and $100 \mathrm{~m}$ depth (Bakalem \& Dauvin, 1995). Ampelisca spinifer was not previously reported from the Spanish Mediterranean coast. A total of 37 specimens have been recorded in Vinaroz, Benicarlo, Peñíscola, Puebla de Farnals, Oliva and Javea, from 14 to $20 \mathrm{~m}$ in fine-sand bottom. Its ecology was previously established between 15 to $182 \mathrm{~m}$ depth on several types of sediment, from muddy to coarse sand but always in sediments with a large amount of mud (Bellan-Santini et al., 1982; Bellan-Santini \& Dauvin, 1988; Marques \& Bellan Santini, 1993).

\section{Ampelisca tenuicornis Liljeborg, 1855}

It was observed in the eastern Atlantic Ocean from northern Norway to the Senegal coast, from o to $510 \mathrm{~m}$ depth; where it can form abundant populations in shallow muddy fine sand community (Bellan-Santini \& Dauvin, 1988). Ampelisca tenuicornis was previously reported from the Mediterranean Spanish coast at the continental shelf of Ebro Delta (western Mediterranean) by Cartes et al. (2007, 2009). We have found a total of 1084 individuals from all studied locations (from 12.4 to $20 \mathrm{~m}$ ), obtaining the highest abundances $\left(956 \mathrm{ind} / \mathrm{m}^{2}\right.$ ) in Gandia during the year 2004. This species was found in sandy and muddy bottom in shallow waters in the eastern and western part of the Mediterranean Sea including the Algerian coast (Bellan-Santini et al., 1982; Bakalem \& Dauvin, 1995).

\section{Family AORIDAE Stebbing, 1899} Autonoe spiniventris Della Valle, 1893

Despite being previously established as Mediterranean endemic (Bellan-Santini et al., 1982), Autonoe spiniventris has since been observed by Martínez \& Aderraga (2001) on the Atlantic coast (San Sebastian, Spain). This species is common in the Bou Ismail and Algiers Bays between 15 and $100 \mathrm{~m}$ depth from sand to muddy coarse sand (Bakalem \& Dauvin, 1995). It was reported from the Spanish 
Table 2. Amphipods species identified during present study. Asterisks indicate new records $\left(^{*}\right)$ and second records $\left({ }^{* *}\right)$ for Spanish Mediterranean Coast. Literature and substratum where each species was found are indicated.

\begin{tabular}{|c|c|c|c|}
\hline Families & Species & Recorded by & Substratum \\
\hline \multirow{6}{*}{ Ampeliscidae } & Ampelisca brevicornis (Costa, 1853) & III, V, XII & A, M, D \\
\hline & Ampelisca diadema (Costa, 1853) & VI, XI, XII & $\mathrm{A}, \mathrm{D}, \mathrm{V}$ \\
\hline & Ampelisca sarsi (Chevreux, 1888)** & VI & $\mathrm{V}, \mathrm{B}$ \\
\hline & Ampelisca spinifer (Reid, 1951)* & This study & A \\
\hline & Ampelisca tenuicornis (Liljeborg, 1855$)^{* *}$ & $\mathrm{XV}$ & M \\
\hline & Ampelisca typica (Bate, 1856) & VI, VIII & A, M, D \\
\hline Amphilochidae & Amphilochus brunneus (Della Valle, 1893) & VI, XV & A \\
\hline Amphithoidae & Amphithoe ramondi (Audouin, 1826) & I, IV, V, VI, VII, VIII, XII, XIV, XVII & $A, V, D, C$ \\
\hline \multirow[t]{4}{*}{ Aoridae } & Aora spinicornis (Afonso, 1976) & IV, V, VII, IX, XVI & $\mathrm{A}, \mathrm{V}$ \\
\hline & Autonoe spiniventris (Della Valle, 1893$)^{* *}$ & XII & $\mathrm{A}, \mathrm{V}$ \\
\hline & Microdeutopus versiculatus (Bate, 1856) & VI, IX, XII & $\mathrm{A}, \mathrm{M}, \mathrm{D}, \mathrm{V}$ \\
\hline & Tethylembos viguieri (Chevreuz, 1911) & I, VI & $\mathrm{A}, \mathrm{M}, \mathrm{D}, \mathrm{V}$ \\
\hline Argissidae & Argissa stebbingi (de Rouville, 1894)* & This study & A \\
\hline \multirow[t]{2}{*}{ Atylidae } & Atylus guttatus (Costa, 1851) & I, IV, V, XII, XVI & $\mathrm{A}, \mathrm{V}$ \\
\hline & Atylus massiliensis (Bellan-Santini, 1975) & III, XII & $\mathrm{A}, \mathrm{V}$ \\
\hline \multirow{3}{*}{ Bathyporeiidae } & Bathyporeia lindstromi (Stebbing, 1906)* & This study & $\mathrm{A}$ \\
\hline & Bathyporeia guilliamsoniana (Bate, 1857) & V, VI, VIII, XII & $\mathrm{A}, \mathrm{V}$ \\
\hline & Bathyporeia borgi (d'Udekem d'Acoz \& Vader, 2005)* & This study & A \\
\hline \multirow[t]{2}{*}{ Caprellidae } & Pariambus typicus (Krøyer, 1844) & III, IX, XIV & $\mathrm{A}, \mathrm{V}$ \\
\hline & Phtisica marina (Slabber, 1769) & I, IV, V, VI, VII, X, XIV, XVI & $\mathrm{A}, \mathrm{V}$ \\
\hline Cheirocratidae & Cheirocratus sundevalli (Liljeborg, 1861$)^{* *}$ & VI & $\mathrm{A}, \mathrm{M}, \mathrm{D}, \mathrm{V}$ \\
\hline \multirow[t]{6}{*}{ Corophiidae } & Leptocheirus hirsutimanus (Bate, 1862$)^{* *}$ & VI & $\mathrm{A}, \mathrm{H}$ \\
\hline & Leptocheirus pectinatus (Norman, 1869) & VI, XIV & $\mathrm{M}, \mathrm{D}, \mathrm{C}$ \\
\hline & $\begin{array}{l}\text { Medicorophium longisetosum (Myers, de-la-Ossa-Carretero \& } \\
\text { Dauvin, 2010) }\end{array}$ & This study & A \\
\hline & Medicorophium runcicorne (Della Valle, 1893 )** & VI & $\mathrm{M}, \mathrm{D}$ \\
\hline & Monocorophium sextonae (Crawford, 1937) & IV, VI, VII, XVI & $\mathrm{A}, \mathrm{M}, \mathrm{V}, \mathrm{H}$ \\
\hline & Siphonoecetes sabatieri (de Rouville, 1894) & III, IV, XII & $\mathrm{A}, \mathrm{V}$ \\
\hline Dexaminidae & Dexamine spinosa (Montagu, 1813) & I, IV,VIII, X, XII, XIV & $\mathrm{V}, \mathrm{H}$ \\
\hline Eusiridae & Apherusa alacris (Krapp-Schickel, 1969)** & VI & $\mathrm{V}$ \\
\hline Isaeidae & Microprotopus maculatus (Norman, 1867) & II, III, VIII, XII & A \\
\hline Ischyroceridae & Ericthonius punctatus (Bate, 1857) & III, IV, V, VI, VIII, XVI & $\mathrm{A}, \mathrm{V}$ \\
\hline \multirow[t]{2}{*}{ Leucothoidae } & Leucothoe inicisa (Robertson, 1892) & II, VIII & A \\
\hline & Leucothoe oboa (Karaman, 1971)** & VI & $\mathrm{A}, \mathrm{D}, \mathrm{H}$ \\
\hline \multirow[t]{5}{*}{ Lysianassidae } & Hippomedon massiliensis (Bellan-Santini, 1965)** & VI & $\mathrm{A}, \mathrm{M}, \mathrm{D}, \mathrm{B}$ \\
\hline & Lepidepecreum longicorne (Bate \& Westwood, 1861$)^{* *}$ & $\mathrm{~V}$ & $\mathrm{~V}$ \\
\hline & Lysianassa costae (Milne-Edwards, 1830 ) & VI, XII, XIV & $\mathrm{A}, \mathrm{M}, \mathrm{D}, \mathrm{V}, \mathrm{B}$ \\
\hline & Orchomenella nana (Kroyer, 1846) & VI, XI & A \\
\hline & Tryphosites longipes (Bate \& Westwood, 1861) & VI, XI, XV & $\mathrm{A}, \mathrm{M}$ \\
\hline Megaluropidae & Megaluropus massiliensis (Ledoyer, 1976) & V, VI, VIII, XII & $\mathrm{A}, \mathrm{M}, \mathrm{V}$ \\
\hline \multirow[t]{3}{*}{ Melitidae } & Maera grossimana (Montagu, 1808) & $\mathrm{I}, \mathrm{IV}, \mathrm{V}, \mathrm{VI}$ & $\mathrm{A}, \mathrm{D}, \mathrm{V}$ \\
\hline & Maera knudseni (Reid, 1951)** & $\mathrm{V}$ & $\mathrm{V}$ \\
\hline & Elasmopus pocillamus (Bate, 1862) & I, IV, VII, X, XII, XIV, XVII & $\mathrm{V}$ \\
\hline \multirow[t]{4}{*}{ Oedicerotidae } & Monoculodes gibbosus (Chevreux, 1888)** & XI & M \\
\hline & Perioculodes longimanus (Bate \& Westwood, 1868) & III, V, VI, VIII, XI, XV & $\mathrm{A}, \mathrm{M}, \mathrm{D}, \mathrm{V}$ \\
\hline & Synchelidium haplocheles (Grube, 1864)** & VIII & A \\
\hline & Synchelidium maculatum (Stebbing, 1906) & $\mathrm{XI}$ & M \\
\hline \multirow[t]{4}{*}{ Photidae } & Gammaropsis maculata (Johnston, 1828) & I, IV, VI, VII & $\mathrm{A}, \mathrm{M}, \mathrm{D}, \mathrm{V}$ \\
\hline & Megamphopus cornutus (Norman, 1869) & VI & $A, M, D, V, B$ \\
\hline & Photis longicaudata (Bate \& Westwood, 1862)* & This study & A \\
\hline & Photis longipes (Della Valle, 1893) & III, VI & $\mathrm{A}, \mathrm{M}, \mathrm{D}, \mathrm{V}$ \\
\hline \multirow[t]{3}{*}{ Phoxocephalidae } & Harpinia crenulata (Boeck, 187 ) & $\mathrm{XI}, \mathrm{XV}$ & M \\
\hline & Harpinia pectinata (Sars, 1891) & III, XI & A \\
\hline & Metaphoxus fultoni (Scott, 189o) & $\mathrm{I}, \mathrm{V}, \mathrm{VI}$ & $\mathrm{A}, \mathrm{D}, \mathrm{V}$ \\
\hline \multirow[t]{2}{*}{ Urothoidae } & Urothoe pulchella (Costa, 1853) & III, VI & A \\
\hline & Urothoe elegans (Costa, 1853)** & $\mathrm{XI}$ & $\mathrm{M}$ \\
\hline
\end{tabular}

References: I, Carbonell (1984); II, Bibiloni (1983); III, Marti (1989); IV, Jimeno (1993); V, Sánchez-Jerez et al. (1999, 2000); VI, Conradi et al. (1995), Conradi \& López-González (1999); VII, Ruffo \& Krapp-Shickel, personal communication in Jimeno (1993) or Conradi \& López-González (1999); VIII, San Vicente \& Sorbe (1999), Munilla \& San Vicente (2005); IX, Sánchez-Moyano et al. (2007); X, Guerra-García et al. (2009a, b); XI, Cartes \& Sorbe (1993, 1999), Cartes et al. (2003); XII, Vázquez-Luis et al. (2008, 2009); XIII, Gonzalez et al. (2008); XIV, Ortiz \& Jimeno (2003); XV, Cartes et al. (2007, 2009); XVI, Delgado et al. (2009); XVII, Izquierdo \& Guerra-García (2010). Substratum: A, sands; M, mud or clayey bottom; D, detrital bottom; H, hard bottom; V, among algae or seaweeds; B, among Bugula neritina and C. coraligene. 
Mediterranean coast among Posidonia oceanica, and Cymodocea nodosa from the Alicante coast (Vazquez-Luis et al., 2009). Its depth-range was established (Bellan-Santini et al., 1998) from 2 to $100 \mathrm{~m}$ in well-sorted sand bottoms and among photophilic algae. We have collected 5825 specimens from 12.4 to $20.0 \mathrm{~m}$. It has been found in all locations, being especially abundant in northern locations (from Vinaroz to Torreblanca) and Canet d'en Berenguer, with a maximum density of $2125 \mathrm{ind} / \mathrm{m}^{2}$ at Vinaroz in 2006.

Family ARGISSIDAE Walker, 1904

Argissa stebbingi de Rouville, 1894

This cosmopolitan species was previously recorded in the Atlantic Ocean, Indian Ocean and Japan Sea. In the Mediterranean Sea, it has been found from 11 to $370 \mathrm{~m}$ in various sediment types (Bellan-Santini et al., 1982, 1998; Grimes et al., 2009). From the Atlantic Iberian coast, Argissa stebbingi was previously reported in the Bay of Biscay (Bachelet et al., 2003) and as the synonym A. hamatipes in Portugal (Marques \& Bellan-Santini, 1993) and San Sebastian coast (Martínez \& Aderraga, 2001). Eleven individuals of this first record for the Mediterranean Spanish coast have been found from 13.9 to $16.5 \mathrm{~m}$ water depth, in Vinaroz, Peñíscola, Torreblanca and Gandia.

Family BATHYPOREIIDAE Bousfield \& Shih, 1994 Bathyporeia borgi d'Udekem d'Acoz \& Vader, 2005

It was described by d'Udekem d'Acoz \& Vader (2005) from specimens of the Tyrrhenian and Adriatic Seas, reporting that Bathyporeia nana Toulmond, 1966 specimens recorded previously in the Mediterranean Sea are actually $B$. borgi. Bathyporeia nana was found in the western basin of the Mediterranean Sea (Bellan-Santini et al., 1989) in sandy beaches from the intertidal zone to about $10 \mathrm{~m}$ depth. Recently, B. borgi was reported on muddy-sand at a depth of $10 \mathrm{~m}$ from the Algerian coast (Grimes et al., 2009). We have found 338 specimens along all locations from 12.4 to $20 \mathrm{~m}$.

\section{Bathyporeia lindstromi Stebbing, 1906}

This endemic Mediterranean species was known on sandy bottoms, in 20 to $30 \mathrm{~m}$ from Italy (Tyrrhenian Sea), Sardinia, Malta and the Israeli coast (Bellan-Santini et al., 1989, 1998; d'Udekem d'Acoz \& Vader, 2005), and it has since been found on fine sand at a depth of $5 \mathrm{~m}$ from the Algerian coast (Grimes et al., 2009). We have collected two individuals in Oliva and Javea at a water depth of 15.6 and $20 \mathrm{~m}$.

Family CHEIROCRATIDAE Ren, 2006 Cheirocratus sundevalli Liljeborg, 1861

This species was widely distributed in the Mediterrranean Sea, the Atlantic Ocean, the Black Sea and the Arctic Ocean from 8 to $157 \mathrm{~m}$, being characteristically on sandy bottoms with loose-lying algae (Bellan-Santini et al., 1982, 1998; Marques \& Bellan-Santini, 1993). It was also found on Posidonia meadows and various sediment types in the Bou Ismail Bay and Annaba Gulf from 8 to $90 \mathrm{~m}$ depth (Bakalem \& Dauvin, 1995). On the Spanish Mediterranean coast, it was recorded for the first time by Conradi \& López-Gonzalez (1999) in sand, mud and detrital bottoms as well as among
Halopteris scorparia from the Andalusian coast in 5 to $30 \mathrm{~m}$ water depth. We have collected 28 individuals from Vinaroz, Benicarlo and Peñíscola in 14 to $15 \mathrm{~m}$.

$$
\begin{gathered}
\text { Family COROPHIDAE Leach, } 1814 \\
\text { Leptocheirus hirsutimanus Bate, } 1862
\end{gathered}
$$

It was observed along the north-eastern Atlantic Ocean and Mediterranean Sea from 7 to 350 m (Bakalem \& Dauvin, 1995; Bellan-Santini et al., 1998). Its ecology was established as detritic and mud coastal bottoms and bathyal muds (Bellan-Santini et al., 1982, 1998) as well as gravelly and coarse sand (Marques \& Bellan-Santini, 1993). Leptocheirus hirsutimanus was first recorded from the Mediterranean Spanish coast by Conradi \& López-Gonzalez (1999) in medium sand, biodetrital and hard bottoms from the Andalucían coast. We have found 26 individuals in Puebla de Farnals at $18.9 \mathrm{~m}$ water depth.

\section{Medicorophium runcicorne Della Valle, 1893}

This species has only been reported from the Mediterranean and Black Seas in mud and mobile substrates and among algae from 15 to $105 \mathrm{~m}$ (Bellan-Santini et al., 1982, 1998; Bakalem \& Dauvin, 1995). Medicorophium runcicorne was recorded for the first time from the Spanish coast by Conradi \& López-Gonzalez (1999) in biodetrital, mud and clayey bottoms from the Andalucían coast. A total of 1304 individuals have been collected. It has been reported in all locations from 12.4 to $20 \mathrm{~m}$ water depth, obtaining the highest abundances in the locations of Gandia and Oliva $\left(325 \mathrm{ind} / \mathrm{m}^{2}\right)$.

\section{Medicorophium longisetosum Myers, de-la-Ossa-Carretero \& Dauvin, 2010}

A total of 365 specimens were collected from all locations with a depth-range of 12.4 to $20 \mathrm{~m}$. Numbers of specimens collected in the ten sampling sites varied from 211 individuals at Vinaroz to one specimen at Javea. The presence of this new species, which is habitual and relatively abundant, is the best example of the necessity for more taxonomic studies in this area. It was fully described in Myers et al. (2010).

$$
\begin{gathered}
\text { Family EUSIRIDAE Stebbing, } 1888 \\
\text { Apherusa alacris Krapp-Schickel, } 1969
\end{gathered}
$$

This Mediterranean endemic species was established inhabiting among seagrasses (Zostera) and fine and coarse sand bottoms from 3 to $25 \mathrm{~m}$ (Bellan-Santini et al., 1982, 1998). It was recorded for the first time in the Spanish Mediterranean coast by Conradi \& López-Gonzalez (1999) among Halopteris escorparia. We have found 12 individuals in the locations of Alcossebre, Torreblanca and Oliva from 12.4 to $15.6 \mathrm{~m}$ in fine-sand bottoms.

\section{Family LEUCOTHOIDAE Dana, 1852 Leucothoe oboa Karaman, 1971}

This species was previously established as a Mediterranean endemic and its ecology was established in muddy bottoms from 14 to $400 \mathrm{~m}$ (Bellan-Santini et al., 1989, 1998), however, it was also reported from the Portuguese coast (Marques \& Bellan-Santini, 1993) on gravelly and coarse sand bottoms from 52 to $97 \mathrm{~m}$ water depth. It was recorded 
in the Oran Gulf at a depth of $80 \mathrm{~m}$ on sandy mud and in the Oran Harbour on mud with shells (Grimes et al., 2009). Leucothoe oboa was first recorded from the Spanish Mediterranean coast by Conradi \& López-Gonzalez (1999) in hard and sand biodetrital bottoms. We have found it in sandy bottoms with specimens of Leucothoe inicisa. We have collected a total of 213 individuals from 12.4 to $20 \mathrm{~m}$ water depth. It has been found in all locations though always in low abundances $\left(40 \mathrm{ind} / \mathrm{m}^{2}\right.$ ).

Family LYSIANASSIDAE Dana, 1849

Hippomedon massiliensis Bellan-Santini, 1965

This Mediterranean endemic species was distributed on sandy and muddy bottoms from 4 to $350 \mathrm{~m}$ (Bellan-Santini et al., $1989,1998)$. It was also recorded from Bou Ismail Bay (10$88 \mathrm{~m}$ ) from sand to muddy gravel (Bakalem \& Dauvin, 1995). Hippomedon massiliensis was only recorded from the Spanish coast by Conradi \& López-Gonzalez (1999) in sand, mud and detrital bottoms as well as among Bugula neritina. We have collected 228 individuals from 12.4 to $20 \mathrm{~m}$ depth, distributed in all locations but always in low densities (up to $40 \mathrm{ind} / \mathrm{m}^{2}$ ).

\section{Lepidepecreum longicorne Bate \& Westwood, 1861}

This species was observed in the north-eastern Atlantic Ocean and Mediterranean Sea at depths ranging from o to $360 \mathrm{~m}$ (Bellan-Santini et al., 1989, 1998; Bakalem \& Dauvin, 1995). Its ecology is established in gravels and sand bottoms as well as abyssal and bathyal muds. Lepidepecreum longicorne was observed on the Spanish Mediterranean coast among Posidonia oceanica meadows along the Alicante coast and the Iberian coast, it was also previously recorded in Portugal (Marques \& Bellan-Santini, 1993). We have found 46 specimens in northern locations (Vinaroz to Alcossebre), from 12.5 to $15 \mathrm{~m}$ water depth.

\section{Family MELITIDAE Bousfield, 1973 Maera knudseni Reid, 1951}

It is distributed in the Atlantic Ocean (West Africa) and the Mediterranean Sea (Bellan-Santini et al., 1982). It was common in Bou Ismail Bay on mud and sandy-muddy gravel between 45 to $100 \mathrm{~m}$ depth (Bakalem \& Dauvin, 1995). Its ecology was established in mud, muddy sands, coarse sands, fine gravel and detritic bottoms with a depth range from 10 to $68 \mathrm{~m}$ (Bellan-Santini et al., 1982, 1998). Maera knudseni was previously observed in Posidonia oceanica meadows along the Alicante coast (Sanchez-Jerez et al., 2000). We have found 18 individuals only in Puebla de Farnals at $18.9 \mathrm{~m}$ water depth.

Family OEDICEROTIDAe Lilljeborg, 1865

Monoculodes gibbosus Chevreux, 1888

This species was previously observed in the north-eastern Atlantic Ocean and Mediterranean Sea in soft bottoms from 10 to $360 \mathrm{~m}$ water depth (Bellan-Santini et al., 1993, 1998). It was reported in the Bejaia Gulf and Bou Ismail Bay on various sediment types ranging from mud to coarse sand and at depths from 24 to $86 \mathrm{~m}$ (Grimes et al., 2009). Monoculodes gibbosus was previously reported on the muddy bottoms of the deep slope in front of Barcelona (western Mediterranean) from 593 to $598 \mathrm{~m}$ water depth (Cartes \& Sorbe, 1999). We have found 14 individuals from Vinaroz, Benicarlo, Peñíscola, Puebla de Farnals and Oliva in 14 to $15.6 \mathrm{~m}$.

\section{Synchelidium haplocheles Grube, 1864}

It is known from the Mediterranean Sea, Atlantic Ocean and Indo-Pacific Ocean (Bellan-Santini et al., 1993, 1998; Bakalem \& Dauvin, 1995), living from 3 to $100 \mathrm{~m}$ water depth on well sorted sand and coastal terrigenous mud bottoms. Synchelidium haplocheles was previously recorded on beaches from the Catalonian coast (Munilla \& San Vicente 2005). We have found 90 specimens at depths from 12.4 to $15.6 \mathrm{~m}$ in northern locations, Puebla de Farnals and Gandia.

Family PHOTIDAE Boeck, 1871

Photis longicaudata Bate \& Westwood, 1862

This cosmopolitan species was observed in the Atlantic Ocean (from Norway to West Africa), the Indian Ocean and the Mediterranean Sea. Its ecology was established from infralittoral, among algae and Posidonia meadows, to bathyal (400 m), among mud and detritic bottoms (Bellan-Santini et al., 1989, 1998; Bakalem \& Dauvin, 1995). Although it was previously recorded from the Atlantic Iberian coast (Marques \& Bellan-Santini, 1993; Matínez \& Adarraga, 2001), Photis longicaudata was not previously reported from the Spanish Mediterranean coast. Two specimens have been collected in Torreblanca at a depth of $13.9 \mathrm{~m}$.

$$
\begin{gathered}
\text { Family UROTHOIDAE Bousfield, } 1979 \\
\text { Urothoe elegans Costa, } 1853
\end{gathered}
$$

This species was observed in the Atlantic Ocean, Indian Ocean and Mediterranean Sea (western, Tyrrhenian, Adriatic, Israel and North Africa) associated with fine sediments distributed from 2 to $644 \mathrm{~m}$ (Bellan-Santini et al., 1989, 1998; Bakalem \& Dauvin, 1995). Urothoe elegans was previously reported on the muddy bottoms of the deep slope in front of Barcelona (western Mediterranean) (Cartes \& Sorbe, 1993, 1999). We have found 143 individuals, in locations at Canet d'en Berenguer, Puebla de Farnals and Javea, from 15.6 to $20 \mathrm{~m}$ water depth.

\section{Species distribution among locations}

Cluster analyses based on species composition showed a segregation of stations according to the north-south axis (Figure 2). In this way, locations from north of the studied area (Groups A and B) obtained similarities among them higher than $60 \%$ and location 10 (Group F), which is sited south of studied area, showed more dissimilarity than other locations.

Changes among these locations were due to a decrease in abundance of species such as Autonoe spiniventris, Perioculodes longimanus or Siphonoecetes sabatieri from north to south. Whereas, other species abundance increased in locations 8 and 9, such as Ampelisca typica, Ampelisca tenuicornis or Medicorophium runcicorne, or from locations 6 to 9 Urothoe pulchella, or from locations 7 to 9 Photis longipes (Table 3).

The influence of geographical situations of each location in amphipod assemblage was reflected in BEST and CCA results. 


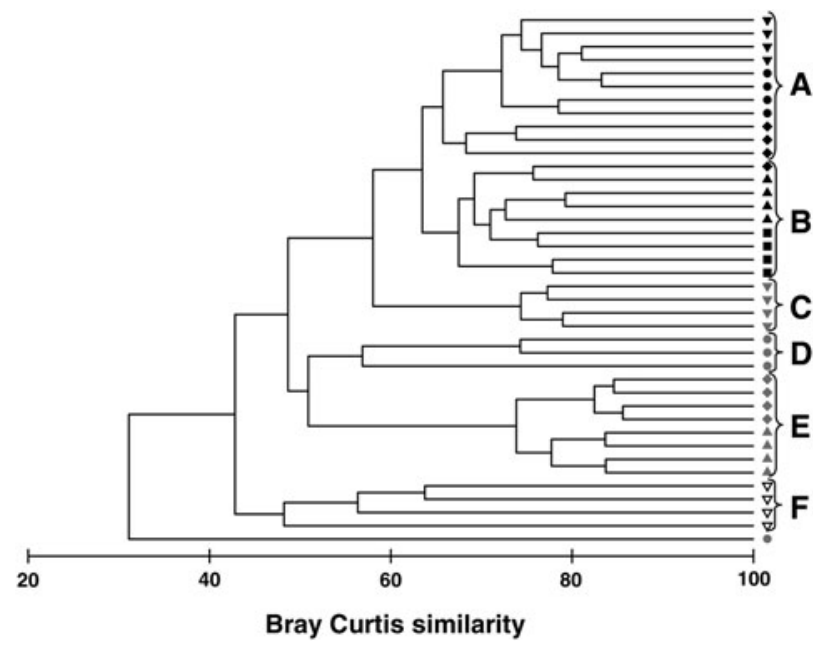

Fig. 2. CLUSTER analysis based on amphipod assemblage of stations (ind/ $\left.\mathrm{m}^{2}\right)$, indicating each location $(\boldsymbol{\nabla}, 1 ; \bullet, 2 ; \bullet, 3 ; \boldsymbol{\Delta}, 4 ; \boldsymbol{\square}, 5 ; \boldsymbol{\nabla}, 6 ; \boldsymbol{\bullet}, 7 ; \bullet, 8$; A, 9; $\triangle, 10)$ and groups established (A, B, C, D, E and F).

Latitude together with depth obtained the highest Spearman correlation (Rho: 0.609 and 0.606 ) with changes in species composition. The CCA showed that both parameters were related since the southern locations are slightly deeper than northern ones (Figure 3; Table 1). Both latitude and depth highly influence benthic communities and were related to other abiotic parameters such as hydrodynamic conditions, temperature, dissolved oxygen, granulometry and organic content. For instance, temperature, influenced by latitude and depth, affect most biological processes and act on growth rates, maturation or reproduction cycle. Despite the fact that species contributing to differences among locations displayed a wide bathymetric distribution, some of them could be less adapted to hydrodynamic processes than others (Bellan-Santini et al., 1998). The fine sand communities, such as the study area, are always influenced by high hydrodynamism which can remove the surface layer (Cardell et al., 1999), in such a way that local changes could change species abundances according to their capacity to shelter.

Table 3. Mean abundance of species contributing more in dissimilarities among groups established in CLUSTER analysis.

\begin{tabular}{|c|c|c|c|c|c|c|}
\hline \multirow[t]{2}{*}{ Species } & \multicolumn{6}{|c|}{ Average abundance (ind $\mathrm{m}^{-2}$ ) } \\
\hline & $\begin{array}{l}\text { Group } \\
\text { A }\end{array}$ & $\begin{array}{l}\text { Group } \\
\text { B }\end{array}$ & $\begin{array}{l}\text { Group } \\
\text { C }\end{array}$ & $\begin{array}{l}\text { Group } \\
\text { D }\end{array}$ & $\begin{array}{l}\text { Group } \\
\text { E }\end{array}$ & $\begin{array}{l}\text { Group } \\
\text { F }\end{array}$ \\
\hline $\begin{array}{l}\text { Ampelisca } \\
\text { tenuicornis }\end{array}$ & 20.45 & 10.19 & 41.67 & 52.78 & 635.42 & 22.92 \\
\hline $\begin{array}{l}\text { Ampelisca } \\
\text { typica }\end{array}$ & 140.15 & 54.63 & 143.75 & 194.44 & 277.08 & $35 \cdot 42$ \\
\hline $\begin{array}{l}\text { Autonoe } \\
\quad \text { spiniventris }\end{array}$ & 778.79 & 535.19 & 560.42 & 72.22 & 52.08 & 25 \\
\hline $\begin{array}{l}\text { Medicorophium } \\
\text { runcicorne }\end{array}$ & 100.76 & 47.22 & 47.92 & 16.67 & 337.5 & 2.08 \\
\hline $\begin{array}{l}\text { Perioculodes } \\
\quad \text { longimanus }\end{array}$ & 220.45 & 187.04 & 89.58 & 16.67 & 63.54 & 16.67 \\
\hline Photis longipes & 96.21 & 27.78 & 95.83 & 438.89 & 382.29 & 85.42 \\
\hline $\begin{array}{c}\text { Siphonoecetes } \\
\text { sabatieri }\end{array}$ & 180.3 & 91.67 & 0 & 22.22 & 8.33 & 39.58 \\
\hline $\begin{array}{l}\text { Urothoe } \\
\text { pulchella }\end{array}$ & 25.76 & 25.93 & 137.5 & 258.33 & 121.88 & 87.5 \\
\hline
\end{tabular}

Other parameters such as mud percentage or organic matter showed a weak correlation (Rho: 0.291 and 0.208 ), whereas percentages of other granulometric sizes showed the lowest correlations $($ Rho $<0.2$ ) with amphipod species composition. Changes in these parameters were related to species differences among close locations. Despite the fact that sediments in the area were homogeneous and low changes in granulometry among locations were registered, grain size and organic content are factors that may be related to food availability and the ability to burrow (Oakden, 1984; Marques \& Bellan-Santini, 1993); as a result light changes in sediment from close areas could produce changes in species composition.

\section{BIOGEOGRAPHICAL CONSIDERATIONS}

The present study recorded a total of 55 total species, but for a limited length of Spanish coast $(250 \mathrm{~km})$ and only for sandy bottoms. Among these species, 30 have a north-eastern Atlantic distribution and 17 have a wide distribution in Atlantic and Indo-Pacific or Arctic Oceans (Bakalem \& Dauvin, 1995; Bellan-Santini et al., 1998; Grimes et al., 2009). Meanwhile, only eight species were considered Mediterranean endemics. Among these endemics, six are reported as first or second records on the Spanish Mediterranean coast; and among the north-eastern Atlantic species Autonoe spiniventris and Leucothoe oboa are known only along the Iberian coast (Marques \& Bellan-Santini, 1993; Martínez \& Aderraga, 2001). Among the 20 species recorded for the first or second time on the Mediterranean coast, only two species Apherusa alacris and the new species Medicorophium longisetosum were absent along the Algerian coast (Bakalem \& Dauvin, 1995; Grimes et al., 2009), and four species, namely the two same species for Algeria, plus the two Bathyporeia species, B. borgi and B. lindstromi, were absent from the French Mediterranean coast. This shows a good resemblance of the continental shelf amphipod fauna at the scale of the western part of the Mediterranean Sea.

A total of six species ( $>10 \%$ of the recorded species) was new for the Spanish coast, and among them a new species was described (Myers et al., 2010). This proves the need to significantly increase the prospection of the amphipods from the Mediterranean Spanish coast. To give some comparative numbers, the French Mediterranean continental shelf accounts for 250 Gammaridea (Dauvin \& Bellan-Santini, 2002). Nevertheless records depended on the sampling efforts among the regions, respectively 240 in the 'Provence-Alpes Côte d'Azur' region which included the Marseilles Gulf where numerous studies were made mainly through the expertise of Denise Bellan-Santini, 100 for the 'Languedoc-Roussillon' region at the frontiers with Spain, and only 78 species around Corsica (Dauvin \& Bellan-Santini, 2002). Recent works on Algerian amphipods, including three orders, i.e. Caprellidea, Gammaridea and Hyperiidea (Bakalem \& Dauvin, 1995; Grimes et al., 2005), revealed that the fauna accounts for 298 species of the 451 species recorded in the mid-1990s for the whole Mediterranean fauna. Using these records, we expected that the total amphipod marine fauna (Caprellidea, Gammaridea and Hyperiidea) of the Mediterranean coast of Spain should include between 250 and 300 species. A first inventory of all 


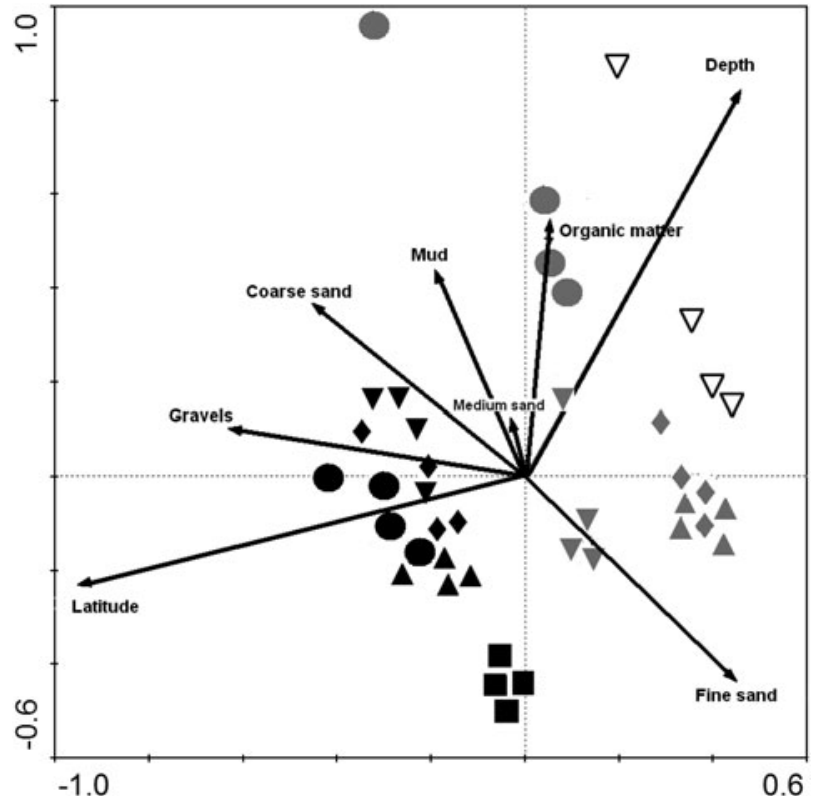

Fig. 3. Results of canonical correspondence analysis (CCA) biplots. Points correspond to samples from locations: $\boldsymbol{\nabla}, 1 ; \bullet, 2 ; \bullet, 3 ; \boldsymbol{\Delta}, 4 ; \boldsymbol{\square}, 5 ; \boldsymbol{\nabla}, 6$; $\mathbf{0}$, $7 ; \Delta, 8 ; \Delta, 9 ; \triangle, 10$. Arrows indicate environmental variables. CCA axis I and CCA axis II had eigenvalues of 0.184 and 0.142 , respectively.

species collected in this area should be completed from published works particularly those of J.M. Guerra-Garcia on caprellids (Guerra-García et al., 2000, 2001a,b, 2002, 2009a,b). Moreover, the higher percentage of endemics among first or second records indicates the need for more sampling studies in order to increase distribution knowledge of Amphipoda species from the Spanish Mediterranean coast.

\section{ACKNDWLEDGEMENTS}

This research would not have been possible without help from many people. We gratefully acknowledge the staff of the Department of Marine Sciences and Applied Biology and of the Station Marine de Wimereux. We also thank Dr Alan Myers for his inestimable collaboration with the species $M$. longisetosum sp. nov. I would like to especially thank Angel Climent Ballester's for her invaluable help. We also acknowledge the contributions of the two anonymous referees on the first version of the manuscript. We gratefully acknowledge CONSOMAR S.A. and Entitat de Sanejament d'Aigües for the financial contribution. We are also grateful to the University of Alicante for awarding a predoctorate grant to J.A.O.C. for a stay in Station Marine de Wimereux (France) and to this host institution for the admission.

\section{REFERENCES}

Bachelet G., Dauvin J.-C. and Sorbe J.C. (2003) An updated checklist of marine and brackish water Amphipoda (Crustacea: Peracarida) of the southern Bay of Biscay. Cahiers de Biologie Marine 44, 121-151.

Bakalem A. and Dauvin J.-C. (1995) Inventaire des crustacés amphipodes (Gammaridea, Caprellidea, Hyperiidea) des Côtes d'Algérie: essai de synthèse. Mesogée 54, 49-62.
Bakalem A., Ruellet T. and Dauvin J.-C. (2009) Benthic indices and ecological quality of shallow Algeria fine sand community. Ecological Indicators 9, 395-408.

Bellan-Santini D. and Costello M.J. (2001) Amphipoda. In Costello M.J., Emblow C.S. and White R. (eds) European Register of Marine Species. A check-list of the marine species in Europe and a bibliography of guides to their identification. Publications Scientifiques du Muséum National d'Histoire Naturelle, Paris. Patrimoines Naturels 50, 295-308. (www. marbef.org/data/erms.php)

Bellan-Santini D. and Dauvin J.-C. (1988) Eléments de synthèse sur les Ampelisca du Nord-est Atlantique. Crustaceana Supplement 13, 2060.

Bellan-Santini D., Diviacco G., Krapp-Schickel G., Myers A. and Ruffo S. (1989) The Amphipoda of the Mediterranean. Part 2. Gammaridea (Haustoriidae to Lysianassidae) (Ruffo S.ed.). Mémoires de l'Institut Océanographique, Monaco 13, 365-576.

Bellan-Santini D., Karaman G., Krapp-Schickel G., Ledoyer M., Myers A.A., Ruffo S. and Schiecke U. (1982) The Amphipoda of the Mediterranean. Part 1. Gammaridea (Acanthonozomatidae to Gammaridae) (Ruffo S.ed.). Mémoires de l'Institut Océanographique, Monaco 13, 1-364.

Bellan-Santini D., Karaman G., Krapp-Schickel G., Ledoyer M. and Ruffo S. (1993) The Amphipoda of the Mediterranean. Part 3. Gammaridea (Melphidipiidae to Talitridae) -IngolfiellideaCaprellidea (Ruffo S.ed.). Mémoires de l'Institut Océanographique, Monaco 13, 577-813.

Bellan-Santini D., Karaman G.S., Ledoyer M., Myers A.A., Ruffo S. and Vader W. (1998) The Amphipoda of the Mediterranean, (Ruffo S.ed.). Part 4. Mémoires de l'Institut Océanographique, Monaco 13, 815-959.

Bibiloni M.A. (1983) Estudio faunístico del litoral de Blanes: V. Sistemática de Moluscos y artrópodos (crustáceos y picnogónidos). Miscelánea Zoológica 7, 43-52.

Carbonell J. (1984) Crustacis de les Illes Medes. Els sistemes naturals de les Illes Medes. Institució Catalana d'Història Natural, Barcelona, 505-529.

Cardell M.J., Sardà R. and Romero J. (1999) Spatial changes in sublittoral soft-bottom polychaete assemblages due to river inputs and sewage discharges. Acta Oecologica 20, 343-351.

Cartes J.E., Jaume D. and Madurell T. (2003) Local changes in the composition and community structure of suprabenthic peracarid crustaceans on the bathyal Mediterranean: influence of environmental factors. Marine Biology 143, 745-758.

Cartes J.E., Ligas A., De Biasi A.M., Pacciardi L. and Sartor P. (2009) Small-spatial scale changes in productivity of suprabenthic and infaunal crustaceans at the continental shelf of Ebro Delta (western Mediterranean). Journal of Experimental Marine Biology and Ecology $378,40-49$.

Cartes J.E., Papiol V., Palanques A., Guillén J. and Demestre M. (2007) Dynamics of suprabenthos of the Ebro Delta (Catalan Sea: western Mediterranean): spatial and temporal patterns and relationships with environmental factors. Estuarine, Coastal and Shelf Science 75, 501515 .

Cartes J.E. and Sorbe J.C. (1993) Les communautés suprabenthiques bathyales de la mer Catalane (Méditerranée Occidentale): données préliminaires sur la répartition bathymétrique et l'abondance des crustacés péracarides. Crustaceana 64, 155-171.

Cartes J.E. and Sorbe J.C. (1999) Deep-water amphipods from the Catalan Sea slope (western Mediterranean): bathymetric distribution, assemblage composition and biological characteristics. Journal of Natural History 33, 1133-1158. 
Castany G., Gallifa A.Y. and Perez M. (1982) Estudio de dos poblamientos bentónicos de sustrato dura de dos localidades del litoral catalán. Oecologia Aquatica 6, 159-161.

Clarke K.R. and Warwick R.M. (1994) Change in marine communities: an approach to statistical analysis and interpretation. 1st edition. Plymouth, UK: Plymouth Marine Laboratory, 144 pp.

Conradi M. and López-Gónzalez P.J. (1999) The benthic Gammaridea (Crustacea, Amphipoda) fauna of Algeciras Bay (Strait of Gibraltar): distributional ecology and some biogeographical considerations. Helgoland Marine Research 53, 2-8.

Conradi M., López-Gónzalez P.J. and Bellan-Santini D. (1995) A new species of Urothoe (Amphipoda, Gammaridea) from the Iberian Peninsula. Cahiers de Biologie Marine 36, 9-13.

Dauvin J.-C. and Bellan-Santini D. (2002) Les crustacés amphipodes Gammaridea benthiques des Côtes françaises métropolitaines: bilan des connaissances. Crustaceana 75, 299-340.

Delgado L., Guerao G. and Ribera C. (2009) The Gammaridea (Amphipoda) fauna in a Mediterranean coastal lagoon: considerations on population structure and reproductive biology. Crustaceana 92, $191-218$.

González A.R., Guerra-García J.M., Maestre M.J., Ruiz-Tabares A., Espinosa F., Gordillo I., Sánchez-Moyano J.E. and García-Gómez J.C. (2008) Community structure of caprellids (Crustacea: Amphipoda: Caprellidae) on seagrasses from southern Spain. Helgoland Marine Research 62, 189-199.

Grimes S., Dauvin J.-C. and Ruellet T. (2009) New records of marine amphipod fauna (Crustacea: Peracarida) on the Algerian coast. Marine Biodiversity Records 2, e151.

Guerra-García J.M., Cabezas M.P., Baeza-Rojano E., Espinosa F. and García-Gómez J.C. (2009a). Is the north side of the Strait of Gibraltar more diverse than the south side? A case study using the intertidal peracarids (Crustacea: Malacostraca) associated to the seaweed Corallina elongata. Journal of the Marine Biological Association of the United Kingdom 89, 387-397.

Guerra-García J.M., Sánchez J.A. and Ros M. (2009b) Distributional and ecological patterns of caprellids (Crustacea: Amphipoda) associated with the seaweed Stypocaulon scoparium in the Iberian Peninsula. Marine Biodiversity Records 2, e134.

Guerra-García J.M. and Izquierdo D. (2010). Caprellids (Crustacea: Amphipoda) associated with the intertidal alga Corallina elongata along the Iberian Peninsula. Marine Biodiversity Records 3, 1-7.

Guerra-García J.M., Sánchez-Moyano J.E. and García-Gómez J.C. (2000) Redescription of Caprella hirsuta Mayer, 1890 (Crustacea, Amphipoda, Caprellidea) from the Strait of Gibraltar. Miscellània Zoologica 23, 69-78.

Guerra-García J.M., Sánchez-Moyano J.E. and García-Gómez J.C. (2001a) A new species of Caprella (Amphipoda: Caprellidea) from Algeciras Bay, Southern Spain. Crustaceana 74, 211-219.

Guerra-García J.M., Sánchez-Moyano J.E. and García-Gómez J.C. (2001b). Two new species of Caprella (Crustacea: Amphipoda: Caprellidea) collected from sandy bottoms in the Strait of Gibraltar. Hydrobiologia 448, 181-192.

Guerra-García J.M., Sánchez-Moyano J.E. and García-Gómez J.C. (2002). Caprella caulerpensis (Crustacea: Amphipoda), a new species of caprellid associated to Caulerpa prolifera (Forsskål) Lamouroux from the Strait of Gibraltar. Journal of the Marine Biological Association of United Kingdom 82, 843-846.

Holme N.A. and McIntyre A.D. (1984) Methods for the study of marine benthos. 2nd edition. London: Blackwell Scientific Publications.

Izquierdo D. and Guerra-García J.M. (2010) Distribution patterns of the peracarid crustaceans associated with the alga Corallina elongata along the intertidal rocky shores of the Iberian Peninsula. Helgoland Marine Research in press. Doi 10.1007/s10152-010-0219-y

Jimeno A. (1993) Contribución al estudio de los Anfípodos de las costas mediterráneas catalanas: estudio faunístico, ecológico, biológico y biogeográfico. $\mathrm{PhD}$ thesis. University of Barcelona, Barcelona, Spain.

Jimeno A. and Turón X. (1995) Gammaridea and Caprellidea of the northeast coast of Spain: ecological distribution on different types of substrata. Polskie Archiwum Hidrobiologii 42, 495-516.

Marques J.C. and Bellan-Santini D. (1993) Biodiversity in the ecosystem of the Portuguese continental shelf: distributional ecology and the role of benthic amphipods. Marine Biology 115, 555-564.

Marti A. (1989) Anfípodos del litoral de Alboraya- Albuixech (Golfo de Valencia, Mediterráneo Occidental). Estudio faunístico y ecológico. Degree thesis. University of Valencia, Valencia, Spain.

Martínez J. and Aderraga I. (2001) Distribución batimétrica de comunidades macrobentónicas de sustrato blando en la plataforma continental de Guipúzcoa (golfo de Vizcaya). Boletin del Instituto Español de Oceanografía 17, 33-48.

Munilla T. and San Vicente C. (2005) Suprabenthic biodiversity of Catalan beaches (NW Mediterranean). Acta Oecologica 27, 81-91.

Myers A.A., de-la-Ossa-Carretero J.A. and Dauvin J.-C. (2010) A new species of Medicorophium Bousfield, M. longisetosum n. sp. from the western Mediterranean, coast of Spain. Zootaxa 2450, 53-60.

Oakden J.M. (1984) Feeding and substrate preference in five species of phoxocephalid amphipods from central California. Journal of Crustacean Biology 4, 233-247.

Ortiz M. and Jimeno A. (2003) Contribución al conocimiento de los Anfípodos (Gammaridea) de Ibiza, Islas Baleares. Graellsia 59, 97-99.

Sanchez-Jerez P., Barberá-Cebrián C. and Ramos-Esplá A.A. (1999) Comparison of the epifauna spatial distribution in Posidonia oceanica, Cymodocea nodosa and unvegetated bottoms: importance of meadow edges. Acta Oecologica 20, 391-405.

Sanchez-Jerez P., Barberá-Cebrián C. and Ramos-Esplá A.A. (2000) Influence of the structure of Posidonia oceanica meadows modified by bottom trawling on crustacean assemblages: comparison of amphipods and decapods. Scientia Marina 64, 319-326.

Sánchez-Moyano J.E., García-Asencio I. and García-Gómez J.C. (2007) Effects of temporal variation of the seaweed Caulerpa prolifera cover on the associated crustacean community. Marine Ecology 28, 324-337.

San Vicente C. and Sorbe J.C. (1999) Spatio-temporal structure of the suprabenthic community from Creixell beach (western Mediterranean). Acta Oecologica 20, 377-389.

Sardá R., Pinedo S., Grémare A. and Taboada S. (2000) Changes in the dynamics of shallow sandy-bottom assemblages due to sand extraction in the Catalan Western Mediterranean Sea. ICES Journal of Marine Science 57, 1446-1453.

Sardá R., Pinedo S. and Martin D. (1996) Seasonal dynamics of macroinfaunal key species inhabiting shallow soft-bottoms in the Bay of Blanes NW Mediterranean. Acta Oecologica 20, 315-326.

Udekem d'Acoz C.d' and Vader W. (2005) The Mediterranean Bathyporeia revisited (Crustacea, Amphipoda, Pontoporeiidae), with the description of a new species. Bollettino del Museo Civico de Storia Naturale di Verona 29, 3-38.

Vázquez-Luis M., Sanchez-Jerez P. and Bayle-Sempere J.T. (2008) Changes in amphipod (Crustacea) assemblages associated with shallow-water algal habitats invaded by Caulerpa racemosa var. cylindracea in the western Mediterranean Sea. Marine Environmental Research 65, 416-426. 
and

Vázquez-Luis M., Sanchez-Jerez P. and Bayle-Sempere J.T. (2009) Comparison between amphipod assemblages associated with Caulerpa racemosa var. cylindracea and those of other Mediterranean habitats on soft substrate. Estuarine, Coastal and Shelf Science 84, 161-170.
Correspondence should be addressed to:

J.A. de-la-Ossa-Carretero

Department of Marine Sciences and Applied Biology University of Alicante

Apartado 99 E-03080 Alicante

Spain

email: ja.ossa@ua.es 